\title{
Relationship between some variables of protein profile and indicators of lipomobilization in dairy cows after calving
}

\author{
Csilla Tóthová, Oskar Nagy and Gabriel Kováč \\ Clinic for Ruminants, University of Veterinary Medicine and Pharmacy, Košice, Slovakia
}

\begin{abstract}
The objective of this study was to determine the concentrations of the main indicators of lipomobilization and selected variables of protein profile in dairy cows after calving, including immunoglobulins and acute phase proteins, as well as to evaluate the relationships between the altered lipid metabolism and changes in protein profile. Into the evaluation we included 54 clinically healthy dairy cows of a Slovak spotted breed, low-land black spotted breed and their crossbreeds in the period of 1-2 weeks after parturition. Blood samples were analysed for non-esterified fatty acids (NEFA, mmol/l), $\beta$-hydroxybutyrate (BHB, $\mathrm{mmol} / \mathrm{l})$, total proteins (TP, $g / l)$, albumin (Alb, $g / l)$, immunoglobulin $G(l g G, g / l)$, haptoglobin $(H p, g / l)$ and serum amyloid $A(S A A, m g / l)$. In cows with concentrations of NEFA above $0.35 \mathrm{mmol} / \mathrm{l}(\mathrm{n}=20)$ we found significantly lower mean serum concentrations of total proteins, albumin and $\mathrm{lg} G$ than in cows with serum NEFA concentrations below $0.35 \mathrm{mmol} / \mathrm{l}(\mathrm{n}=34)(P<0.001)$. On the other hand, cows with higher values of NEFA showed significantly higher mean concentrations of $\mathrm{BHB}, \mathrm{Hp}$ and SAA $(P<0.001)$. The concentrations of NEFA significantly negatively correlated with the values of TP $(P<0.001)$, albumin $(P<0.01)$ and $\lg G(P<0.001)$. Significant positive correlations were found between the concentrations of NEFA and BHB, Hp, as well as SAA $(P<0.001)$. Similar correlations were also found between the values of $B H B$ and the variables of protein profile except for albumin. This study indicates strong relationships between NEFA and selected variables of protein profile in cows after parturition.
\end{abstract}

Keywords: dairy cows, non-esterified fatty acids, acute phase proteins, lipomobilization, postcalving period

Abbreviations: Alb: albumin, BHB: beta-hydroxybutyrate, ELISA: enzyme linked immunosorbent assay, Hp: haptoglobin, IgG: immunoglobulin G, IgM: immunoglobulin M, NEFA: non-esterified fatty acids, SAA: serum amyloid A, TP: total proteins

Archiv Tierzucht 57 (2014) 19, 1-9

doi: 10.7482/0003-9438-57-019

Corresponding author:

Csilla Tóthová; email: tothova@uvm.sk

Clinic for Ruminants, University of Veterinary Medicine and Pharmacy, Komenskeho 73, 04181 Kosice, Slovakia

@ 2014 by the authors; licensee Leibniz Institute for Farm Animal Biology (FBN), Dummerstorf, Germany.

This is an Open Access article distributed under the terms and conditions of the Creative Commons Attribution 3.0 License (http://creativecommons.org/licenses/by/3.0/).
Received: 26 February 2014

Accepted: 21 May 2014

Online: 30 June 2014 


\section{Introduction}

The time around parturition (transition period) is the most important and difficult period for high-yielding dairy cows, which is characterized by a high incidence of metabolic, infectious, and reproductive disorders (Goff \& Horst 1997, Kelton et al. 1998). Roughly it spans from 3 weeks before to 3 weeks after parturition, and is defined as the change from a gestational non-lactating to a non-gestational lactating state (Mulligan \& Doherty 2008, Contreras $\&$ Sordillo 2011). High-yielding dairy cows suffer from negative energy balance during the first weeks of lactation because of energy expenditure due to milk production and limited feed intake (Nielen et al. 1994). Under negative energy balance or low concentrations of insulin, the secretion of hormone-sensitive lipase is stimulated, triggering lipolysis with the subsequent release of fatty acids in its non-esterified form (non-esterified fatty acids - NEFA) to the bloodstream through a process known as lipid mobilization (Herdt 2000, Melendez et al. 2009). The NEFA are converted to more available energy substrates, the liver transforms them into ketone bodies. The most common ketone body in dairy cows is betahydroxybutyrate (BHB). NEFA and BHB are the most important blood indicators to assess the degree of negative energy balance and lipid mobilization (González et al. 2011).

The metabolic changes occurring in transition dairy cows may have consequences on cow's health causing severe economic losses for dairy farmers due to drop in milk yield and increase in culling rates (Goff \& Horst 1997, Jorritsma et al. 2001). Studies in human medicine demonstrated that high concentrations of NEFA are linked to metabolic and inflammatory diseases, induce inflammation and affect immune function (Zhang et al. 2006, Yaqoob \& Calder 2007). Increases in blood lipid content and higher concentrations of serum NEFA have been associated with an increased incidence of periparturient diseases (retained foetal membranes, displacement of the abomasums) also in cattle and predispose dairy cows to inflammatory-based diseases (mastitis, metritis, lameness) (Dyk et al. 1995, Sordillo et al. 2009). In veterinary medicine, the complex pathophysiology of changes in blood lipids and how they affect dairy cow's immunity during the transition period are not yet completely understood. The relationships between some variables related to energetic metabolism and the activation of acute phase response in dairy cows after calving were evaluated previously (Bossaert et al. 2012, Tóthová et al. 2013). However, studies dealing with the evaluation of the association between the concentrations of serum NEFA in cows after calving and changes in protein metabolism are rather scarce. Therefore, this study was aimed at the determination of main blood indicators of lipomobilization and selected variables of protein metabolism in dairy cows shortly after calving, and to describe the possible relationships between the altered lipid metabolism and changes in protein profile, including immunoglobulins and acute phase proteins.

\section{Material and methods}

\section{Animals and sample collection}

The study was carried out on 54 multiparous high-yielding dairy cows (from second to fifth calving) of a Slovak spotted, low-land black spotted breed and their crossbreeds from three conventional dairy farms (from 340 to 420 dairy cows in a herd) under similar husbandry, 
management and feeding conditions (corn silage, hay and concentrates). The average herd milk production at these farms ranged from 7105 to 8350 litres per cow. The age of the monitored cows ranged from 3.5 to 8 years and they were in the period of $1-2$ weeks after parturition. The daily milk yield of the evaluated animals ranged from 28 to $36 \mathrm{~L}$. The animals were housed in free-stalls, and fed twice a day diets for lactating cows with free access to water in automatic drinking troughs. The cows were milked twice a day. Before sample collection, the cows were examined clinically using standard general clinical examination procedures (Jackson \& Cockcroft 2002). None of the cows developed clinical signs of diseases during the time of observation ( 2 weeks after calving).

The analyses of evaluated parameters were performed in blood serum. Blood for the investigations was taken by direct puncture of $v$. jugularis. Blood samples were collected into plastic tubes with serum clot activator (Meus, Piove di Sacco, Italy). The separated serum was stored at $-20^{\circ} \mathrm{C}$ until analysed for indicators of lipomobilization NEFA ( $\left.\mathrm{mmol} / \mathrm{l}\right), \mathrm{BHB}$ $(\mathrm{mmol} / \mathrm{l})$, and selected variables of protein metabolism - total proteins (TP, $\mathrm{g} / \mathrm{l})$, albumin (Alb, $g / l)$, immunoglobulin $\mathrm{G}(\mathrm{lgG}, \mathrm{g} / \mathrm{l})$, and acute phase proteins - haptoglobin $(\mathrm{Hp}, \mathrm{g} / \mathrm{l})$ and serum amyloid $A(S A A, m g / l)$.

\section{Laboratory analyses}

The concentrations of NEFA were assessed using commercial diagnostic kits (Randox, Crumlin, UK) by enzymatic colorimetric method. The values of BHB, TP, and Alb were determined using commercial diagnostic kits (Randox, Crumlin, UK) on automatic biochemical analyser ALIZE (Lisabio, Pouilly en Auxois, France). The concentrations of lgG were analysed by enzyme linked immunosorbent assay (ELISA) using commercially available diagnostic kits (Cusabio, Wuhan, China). Haptoglobin was assessed using commercial colorimetric kits (Tridelta Development, Maynooth, Ireland) in microplates, based on $\mathrm{Hp}$-haemoglobin binding and preservation of the peroxidase activity of the bound haemoglobin at low $\mathrm{pH}$. Serum amyloid A was analysed by sandwich ELISA method using commercial kits (Tridelta Development, Maynooth, Ireland). The reading of absorbencies and the consecutive calculation of final concentrations of $\lg$, $\mathrm{Hp}$, and SAA were performed on automatic microplate reader Epoch (BioTek, Winooski, VT, USA).

The obtained results from evaluated cows were divided into two groups according to the measured concentrations of NEFA and presence of lipomobilization: Group A $(n=34)-$ cows with serum concentrations of NEFA below $0.35 \mathrm{mmol} / \mathrm{l}$ and Group $B(n=20)-$ cows with serum concentrations of NEFA above $0.35 \mathrm{mmol} / \mathrm{l}$.

\section{Statistical analyses}

Arithmetic means and standard deviations for each evaluated variable and group of cows were calculated using descriptive statistical procedures. Unpaired Student's t-test was used to compare and to evaluate the significance of the differences in means between the groups of cows. Relationships between the concentrations of the evaluated variables in the monitored cows were calculated by linear regression and Pearson correlation test, including the correlation coefficient and significance of the correlation. All statistical analyses were done using the programme GraphPad Prism V5.02 (GraphPad Software Inc., La Jolla, CA, USA). 


\section{Results}

The results of the concentrations of selected variables of energetic and protein metabolism characterized by average values and standard deviations, as well as the evaluation of significance of differences in means between two groups of cows are given in Table 1, and on Figure 1 and 2 . The analyses of relationships between monitored variables in cows are presented in Table 2.

The mean value of NEFA in cows of Group A was significantly lower than in cows of Group $\mathrm{B}(P<0.001$, Table 1). The values of BHB in cows with serum concentrations of NEFA above $0.35 \mathrm{mmol} / \mathrm{l}$ were significantly higher compared to cows with concentrations of NEFA below $0.35 \mathrm{mmol} / \mathrm{I}(P<0.001)$. On the other hand, the concentrations of total serum proteins, albumin and lgG were significantly lower in cows with NEFA values above $0.35 \mathrm{mmol} / \mathrm{I}(P<0.001)$. While in cows with serum NEFA concentrations below $0.35 \mathrm{mmol} / \mathrm{l}$ (Group A) the median of $\mathrm{lgG}$ concentrations was $25.25 \mathrm{~g} / \mathrm{l}$ and the individual values ranged from 17.60 to $31.75 \mathrm{~g} / \mathrm{l}$, in cows with NEFA values above $0.35 \mathrm{mmol} / \mathrm{I}$ (Group B) the median $\mathrm{lgG}$ concentration was $15.95 \mathrm{~g} / \mathrm{l}$,

Table 1

Comparison of the concentrations of selected parameters of energetic and protein metabolism between the two groups of dairy cows (mean \pm SD)

\begin{tabular}{lccc}
\hline \multirow{2}{*}{ Parameters } & \multicolumn{2}{c}{ Group of cows } & \multirow{2}{*}{$P$} \\
\cline { 2 - 3 } & $\mathrm{A}(\mathrm{n}=34)$ & $\mathrm{B}(\mathrm{n}=20)$ & $<0.001$ \\
\hline $\mathrm{NEFA}, \mathrm{mmol} / \mathrm{l}$ & $0.18 \pm 0.08$ & $0.87 \pm 0.34$ & $<0.001$ \\
$\mathrm{BHB}, \mathrm{mmol} / \mathrm{l}$ & $0.53 \pm 0.19$ & $0.74 \pm 0.18$ & $<0.001$ \\
$\mathrm{TP}, \mathrm{g} / \mathrm{l}$ & $84.6 \pm 5.9$ & $78.2 \pm 5.5$ & $<0.001$ \\
$\mathrm{Alb}, \mathrm{g} / \mathrm{l}$ & $40.2 \pm 2.6$ & $37.0 \pm 3.3$ & $<0.001$ \\
$\mathrm{lgG}, \mathrm{g} / \mathrm{l}$ & $25.0 \pm 3.5$ & $16.3 \pm 2.7$ & $<0.001$ \\
$\mathrm{Hp}, \mathrm{g} / \mathrm{l}$ & $0.14 \pm 0.06$ & $0.72 \pm 0.44$ & $<0.001$ \\
$\mathrm{SAA}, \mathrm{mg} / \mathrm{l}$ & $10.3 \pm 14.2$ & $107.8 \pm 29.5$ &
\end{tabular}

Group A: cows with serum concentrations of NEFA below $0.35 \mathrm{mmol} / \mathrm{l}$, Group B: cows with serum concentrations of NEFA above $0.35 \mathrm{mmol} / \mathrm{l}, P$ : significance of the differences of means between the groups of cows

Table 2

Regression analysis of the relationship between the concentrations of selected parameters of energetic and protein metabolism in cows

\begin{tabular}{lccccccc}
\hline Parameters & & $\begin{array}{c}\text { NEFA, } \\
\mathrm{mmol} / \mathrm{l}\end{array}$ & $\mathrm{Hp}, \mathrm{g} / \mathrm{l}$ & $\mathrm{SAA}, \mathrm{mg} / \mathrm{l}$ & $\mathrm{TP}, \mathrm{g} / \mathrm{l}$ & Alb, g/l & lgG, g/l \\
\hline $\mathrm{NEFA}, \mathrm{mmol} / \mathrm{l}$ & $\mathrm{R}$ & - & 0.5878 & 0.8110 & -0.4358 & -0.3953 & -0.6382 \\
& $P$ & - & $<0.001$ & $<0.001$ & $<0.001$ & $<0.01$ & $<0.001$ \\
& $\mathrm{R}$ & 0.4479 & 0.6024 & 0.4792 & -0.3483 & -0.2383 & -0.4527 \\
$\mathrm{BHB}, \mathrm{mmol} / \mathrm{l}$ & $P$ & $<0.001$ & $<0.001$ & $<0.001$ & $<0.01$ & $>0.05$ & $<0.001$ \\
& & & & & & &
\end{tabular}

R: correlation coefficient; $P$ : significance of the correlation 
and the measured values ranged from 12.10 to $23.30 \mathrm{~g} / \mathrm{l}$ (Figure 1). More detailed analysis of individual $\lg \mathrm{G}$ concentrations showed that while in Group A $50 \%$ of measured values ranged from 21.95 to $27.63 \mathrm{~g} / \mathrm{l}$, in Group B this range was from 14.60 to $17.28 \mathrm{~g} / \mathrm{l}$.

An opposite trend was found in the concentrations of evaluated acute phase proteins, with significantly higher values of $\mathrm{Hp}$ and SAA in cows with serum concentrations of NEFA above $0.35 \mathrm{mmol} / \mathrm{l}(P<0.001$, Table 1$)$. The median concentration of $\mathrm{Hp}$ in cows with NEFA concentrations below $0.35 \mathrm{mmol} / \mathrm{l}$ (Group A) was $0.13 \mathrm{~g} / \mathrm{l}$, with the individual values ranged from 0.01 to $0.26 \mathrm{~g} / \mathrm{l}$ (Figure 2a). The median of $\mathrm{Hp}$ concentrations in cows of Group B was higher $(0.82 \mathrm{~g} / \mathrm{l})$, and the measured concentrations showed wider range of individual values (from 0.13 to $1.71 \mathrm{~g} / \mathrm{l})$. Similar trend was observed in the concentrations of SAA with approximately 10 fold higher mean value in cows with higher values of NEFA. The median concentration of SAA in cows from Group A was $4.70 \mathrm{mg} / \mathrm{l}$, and the individual values ranged from 0.30 to $64.50 \mathrm{mg} / \mathrm{l}$ (Figure 2b). The median of SAA concentrations in cows from Group B was higher $(109.00 \mathrm{mg} / \mathrm{l})$, and the individual values ranged from 62.00 to $166.00 \mathrm{mg} / \mathrm{l}$.

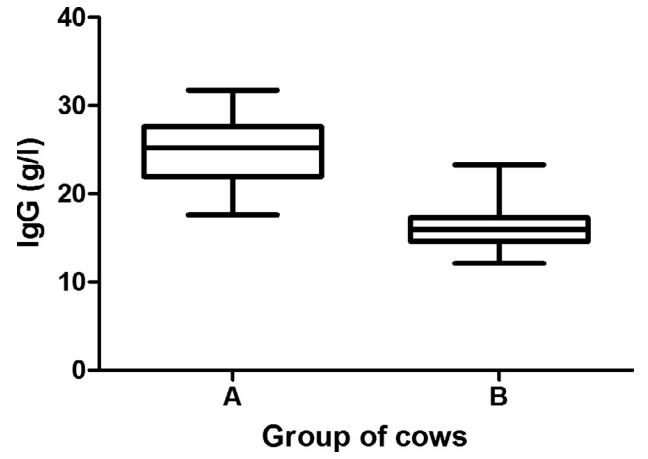

a

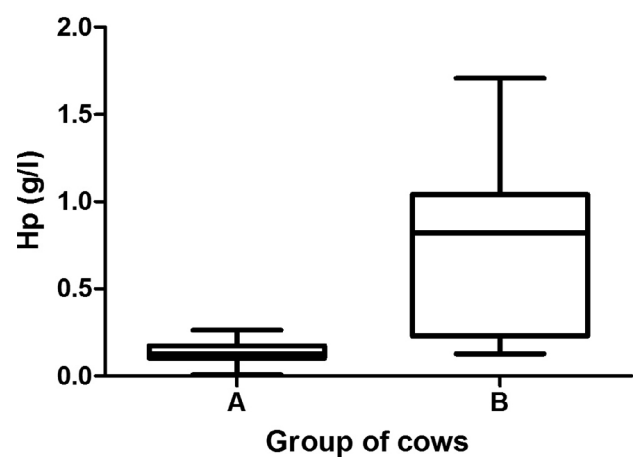

Figure 1

Concentrations of $\lg G$ in serum of cows with NEFA concentrations below $0.35 \mathrm{mmol} / \mathrm{l}(\mathrm{A})$ and above $0.35 \mathrm{mmol} / \mathrm{l}(\mathrm{B})$. The plots show the median (line within box), 25th and 75th percentiles (box), minimum and maximum values (whiskers).

Figure 2

Concentrations of $\mathrm{Hp}(\mathrm{a})$ and SAA (b) in serum of cows with NEFA concentrations below $0.35 \mathrm{mmol} / \mathrm{l}(\mathrm{A})$ and above $0.35 \mathrm{mmol} / \mathrm{I}(\mathrm{B})$. The plots show the median (line within box), 25th and 75th percentiles (box), minimum and maximum values (whiskers). 
By the assessment of the correlations between the evaluated variables (Table 2) we recorded a significant negative correlation between the concentrations of NEFA and total proteins $(P<0.001)$, albumin $(P<0.01)$ and $\lg G(P<0.001)$. On the other hand, the concentrations of NEFA in cows after parturition significantly positively correlated with the values of $\mathrm{BHB}, \mathrm{Hp}$ and SAA $(P<0.001)$. Similar correlations were also found between the values of BHB and the variables of protein profile except for albumin $(P>0.05)$.

\section{Discussion}

Studies in human medicine demonstrated that high concentrations of NEFA induce low-grade inflammation and affect immune function (Hansson 2005, Zhang et al. 2006). In dairy cows, metabolic status can influence the incidence of peripartum diseases, including diseases that are not directly of metabolic origin (metritis, uterine diseases, mastitis) (Kaneene et al. 1997, Melendez et al.2009). Geishauser et al. (2000) and LeBlanc et al. (2005) showed that peripartum cows with marked fat mobilisation have an increased risk for displaced abomasum. The mechanism of association between metabolic changes and inflammatory diseases around calving is not entirely clear, but may be mediated through diminished immune-cell functions (Gilbert etal. 1993). Our study showed in dairy cows with higher serum NEFA values significantly lower concentrations of immunoglobulin $\mathrm{G}$, and high concentrations of NEFA, as well as BHB, correlated negatively with the diminished concentrations of IgG. Similarly, Mösch (2011) demonstrated that the increased concentrations of NEFA on the 3rd day of lactation were associated with decreased concentrations of lgG. Moreover, higher concentrations of NEFA correlated with the reduced concentrations of lgG, while the concentrations of BHB do not exhibit a correlation with the values of IgG. In the study presented by Melendez et al. (2009), overconditioned cows at calving had higher concentrations of NEFA and lower concentrations of IgM post partum. Lacetera et al. (2004) assessed the effect of various concentrations of NEFA on lymphocyte function of heifers and found inhibited IgM secretion by bovine peripheral blood mononuclear cells at concentrations of NEFA of 2, 1, 0.5 and $0.25 \mathrm{mmol} / \mathrm{l}$. This immunosuppression modulated by NEFA was also demonstrated in ewes by Lacetera et al. (2002). They found significantly inhibited secretion of IgM by higher concentrations of NEFA, while higher concentrations of BHB do not inhibited the lgM secretion. According to Gilbert et al. (1993) and Kaneene et al. (1997) peripartum changes in leukocyte function probably are related to the same parturition-associated metabolic and endocrine events, as are changes in NEFA and cholesterol concentrations in serum. These authors concluded, that the extent of peripartum changes in NEFA concentrations is directly or indirectly related to the extent of peripartum reduction in leukocyte function. Contreras et al. (2010) indicated that changes in the concentration and composition of plasma directly affect white blood cell function due to changing of the composition of the cellular membrane of blood cells, or by altering the internal communication of white blood cells. Thus, lower concentrations of lgG in cows with higher concentrations of NEFA observed in our study, may be caused by changes in blood lipid content during periods of lipid mobilization.

The results presented in the study showed in cows with higher concentrations of NEFA significantly lower values of total serum proteins and albumin. Moreover, the concentrations of NEFA negatively correlated with the total protein and albumin concentrations. Similar 
findings were reported by González et al. (2011), who found in cows with high lipid mobilization lower serum concentrations of total proteins, albumin, as well as urea compared to cows with low lipomobilization. According to Bobe et al. (2004), liver lesions caused by fatty infiltration as a consequence of lipomobilization are typically observed in high producing dairy cows during the first stage of lactation. The main indicators of hepatic lesions and function are the liver enzymes, but the serum concentrations of metabolites like glucose, proteins and urea are also indicators of hepatic functionality and decreases in their concentrations may reflect fat infiltration in animals with high lipomobilization (Adewuyi et al. 2005). West (1990) also reported, that fat infiltration into the liver may affect the concentrations of some blood components, including the diminished concentrations of glucose, total proteins, albumin, and urea. Moreover, González et al. (2011) found, similarly to our results, a significant correlation between serum NEFA values and the concentrations of total proteins. Thus, in the study found changes in the protein metabolism characterized by lower concentrations of total proteins and albumin in cows with higher NEFA values may be a consequence of alterations in liver functions in the affected animals.

An opposite trend was observed in the concentrations of evaluated acute phase proteins with higher values of $\mathrm{Hp}$ and SAA in cows with higher concentrations of NEFA. Parturition with following metabolic challenges constitutes a potentially stressful event for the dairy cow. One of the ways how an animal can manifest stress is in the form of activated acute phase response, including increased production of acute phase proteins by liver. The physiological processes taking place around the time of parturition, especially increase in myometrial activity, involution of the uterus, as well as degeneration and regeneration of the endometrium, may be also responsible for higher concentrations of acute phase proteins in blood serum (Regassa \& Noakes 1999). On the other hand, the periparturient period is characterized by a sudden increase in energy requirements imposed by the onset of lactation and by negative energy balance (Leroy et al. 2008). A significant adaptation to the aforementioned negative energy balance during the transition period is the mobilization of fat from body stores and the release of non-esterified fatty acids into the blood stream. Animals may react to these disturbances in their homeostasis and changes in metabolism with a set of physiological changes, including changes in the concentration of some plasma proteins, especially acute phase proteins. According to Bernabucci et al. (2005) and Sordillo et al. (2009) increased circulating NEFA concentrations are directly associated with increased systemic inflammatory conditions, and large amounts of adipose stores during time of energy deficiency are linked with adverse health effects on the transition cow. Other researches demonstrated also a clear relationship between nutrition, inflammation and disease susceptibility, and that elevated NEFA concentrations are positive risk factors for many inflammatory periparturient diseases in dairy cows (Goff 2006, Calder 2008, Wood et al. 2009). Many of the changes occurring during the acute phase response may be beneficial for the host, but may also have some undesirable consequences for the transition period (Gruys et al. 2005). For example, lower concentrations of negative acute phase proteins, including albumin, have been associated with decreased liver function, reproductive performance, and impaired immunocompetence (Bertoni et al. 2008).

Presented results indicate strong relationships between the concentrations of nonesterified fatty acids, as well as BHB and selected variables related to protein metabolism 
shortly after calving. The study demonstrates that metabolic changes associated with energy imbalance and fat mobilization may be related to alterations in protein metabolism and immune function. These data contribute to the better understanding of the complicated metabolic changes occurring in dairy cows after calving. However, further studies are needed to investigate in detail the association of changes in protein profile, including the acute phase response, with alterations in lipid metabolism and liver variables.

\section{Acknowledgements}

This work was supported by the Slovak Research and Development Agency under contract No. APVV-0475-10 and by VEGA Grants No. 1/0592/12 and 1/0447/14 from the Ministry of Education.

\section{References}

Adewuyi AA, Gruys E, van Eerdenburg FJCM (2005) Non esterified fatty acids (NEFA) in dairy cattle. A review. Vet Q 27, 117-126

Bobe G, Young JW, Beitz DC (2004) Invited review: Pathology, Etiology, Prevention, and Treatment of Fatty Liver in Dairy Cows. J Dairy Sci 87, 3105-3124

Bernabucci U, Ronchi B, Lacetera N, Nardone A (2005) Influence of Body Condition Score on Relationships Between Metabolic Status and Oxidative Stress in Periparturient Dairy Cows. J Dairy Sci 88, 2017-2026

Bertoni G, Trevisi E, Han X, Bionaz M (2008) Effects of Inflammatory Conditions on Liver Activity in Puerperium Period and Consequences for Performance in Dairy Cows. J Dairy Sci 91, 3300-3310

Bossaert P, Trevisi E, Opsomer G, Bertoni G, De Vliegher S, Leroy JLMR (2012) The association between indicators of inflammation and liver variables during the transition period in high-yielding dairy cows: An observational study. Vet J 192, 222-225

Calder PC (2008) The relationship between the fatty acid composition of immune cells and their function. Prostaglandins Leukot Essent Fatty Acids 79, 101-108

Contreras GA, O'Boyle NJ, Herdt TH, Sordillo LM (2010) Lipomobilization in periparturient dairy cows influences the composition of plasma nonesterified fatty acids and leukocyte phospholipid fatty acids. J Dairy Sci 93, 2508-2516

Contreras GA, Sordillo LM (2011) Lipid mobilization and inflammatory responses during the transition period of dairy cows. Comp Immunol Microbiol Infect Dis 34, 281-289

Dyk PB, Emery RS, Liesman JL, Bucholtz HF, VandeHaar MJ (1995) Peripartum non-esterified fatty acids in plasma are higher in cows developing periparturient health problems. J Dairy Sci 78 (Suppl.), 264

Geishauser T, Leslie K, Duffield T (2000) Metabolic aspects in the etiology of displaced abomasum. Vet Clin North Am Food Anim Pract 16, 255-265

Gilbert RO, Gröhn YT, Miller PM, Hoffman DJ (1993) Effect of parity on periparturient neutrophil function in dairy cows. Vet Immunol Immunopathol 36, 75-82

Goff JP, Horst RL (1997) Physiological Changes at Parturition and Their Relationship to Metabolic Disorders. J Dairy Sci 80, 1260-1268

González FD, Muiño R, Pereira V, Campos R, Benedito JL (2011) Relationship among blood indicators of lipomobilization and hepatic function during early lactation in high-yielding dairy cows. J Vet Sci 12, 251255

Gruys E, Toussaint MJM, Niewold TA, Koopmans SJ (2005) Acute phase reaction and acute phase proteins. J Zhejiang Univ Sci B 6, 1045-1056 
Hansson GK (2005) Inflammation, Artheriosclerosis, and Coronary Artery Disease. N Eng J Med 352, 1685-1695

Herdt TH (2000) Ruminant adaptation to negative energy balance. Influences on the etiology of ketosis and fatty liver. Vet Clin North Am Food Anim Pract 16, 215-230

Jackson PGG, Cockcroft PD (2002) Clinical examination of farm animals. Blackwell Science Ltd., Blackwell Publishing Company, Oxford et al., United Kingdom

Jorritsma R, Jorritsma H, Schukken YH, Bartlett PC, Wensing T, Wentink GH (2001) Prevalence and indicators of post partum fatty infiltration of the liver in nine commercial dairy herds in The Netherlands. Livest Prod Sci 68, 53-60

Kaneene JB, Miller RA, Herdt TH, Gardiner JC (1997) The association of serum nonesterified fatty acids and cholesterol, management and feeding practices with peripartum disease in dairy cows. Prev Vet Med 31, 59-72

Kelton DF, Lissemore KD, Martin RE (1998) Recommendations for Recording and Calculating the Incidence of Selected Clinical Diseases of Dairy Cattle. J Dairy Sci 81, 2502-2509

Lacetera N, Franci O, Scalia D, Bernabucci U, Ronchi B, Nardone A (2002) Effects of nonesterified fatty acids an $\beta$-hydroxybutyrate on functions of mononuclear cells obtained from ewes. Am J Vet Res 63, 414-418

Lacetera N, Scalia D, Franci O, Bernabucci U, Ronchi B, Nardone A (2004) Effects of Nonesterified Fatty Acids on Lymphocyte Function of Dairy Heifers. J Dairy Sci 87, 1012-1014

LeBlanc SJ, Leslie KE, Duffield TF (2005) Metabolic Predictors of Displaced Abomasum in Dairy Cattle. J Dairy Sci 88, 159-170

Leroy JLMR, Vanholder T, Van Knegsel ATM, Garcia-Ispierto I, Bols PEJ (2008) Nutrient Prioritization in Dairy Cows Early Postpartum: Mismatch Between Metabolism and Fertility? Reprod Domest Anim 43 (Suppl.), 96-103

Melendez P, Marin MP, Robles J, Rios C, Duchens M, Archbald L (2009) Relationship between serum nonesterified fatty acids at calving and the incidence of periparturient diseases in Holstein dairy cows. Theriogenology $72,826-833$

Mösch A (2011) [Parameters of energy metabolism and immunoglobulin $G$ in the serum of dairy cows in the peripartal period]. Doctoral Thesis, Freie Universität Berlin, Berlin, Germany [in German]

Mulligan FJ, Doherty ML (2008) Production diseases of the transition cow. Vet J 176, 3-9

Nielen M, Aarts MG, Jonkers AG, Wensing T, Schukken YH (1994) Evaluation of two cowside tests for the detection of subclinical ketosis in dairy cows. Can Vet J 35, 229-232

Regassa F, Noakes DE (1999) Acute phase protein response of ewes and the release of PGFM in relation to uterine involution and the presence of intrauterine bacteria. Vet Rec 144, 502-506

Sordillo LM, Contreras GA, Aitken SL (2009) Metabolic factors affecting the inflammatory response of periparturient dairy cows. Anim Health Res Rev 10, 53-63

Tóthová C, Nagy O, Kováč G (2013) Changes in the concentrations of selected acute phase proteins and variables of energetic profile in dairy cows after parturition. J Appl Anim Res 42, 278-283

Yaqoob P, Calder PC (2007) Fatty acids and immune functions: new insights into mechanisms. Br J Nutr 98 (Suppl.), 41-45

West HJ (1990) Effect on liver function of acetonaemia and the fat cow syndrome in cattle. Res Vet Sci 48, 221-227

Wood LG, Scott HA, Garg ML, Gibson PG (2009) Innate immune mechanisms linking non-esterified fatty acids and respiratory disease. Prog Lipid Res 48, 27-43

Zhang WY, Schwartz E, Wang Y, Attrep J, Li Z, Reaven P (2006) Elevated Concentrations of Nonesterified Fatty Acids Increase Monocyte Expression of CD11b and Adhesion to Endothelial Cells. Arterioscler Thromb Vasc Biol 26, 514-519 